\title{
REPRESENTATION OF MARXISM IN VAMPIRES IN HAVANA
}

\author{
Abdul Aziz Turhan Kariko \\ Jurusan Sastra Inggris, Fakultas Bahasa dan Budaya, Bina Nusantara University \\ Jln. Kemanggisan Ilir III No. 45, Palmerah, Jakarta Barat 11480
}

\begin{abstract}
Article presents an animated film related to ideological development in Cuba. This effort brings an understanding of ideology and cultural policy of Cuba as a communist state. Presentation begins with summary of the story, history and background, ideological concepts, and the movie Vampires in Havana itself. It is concluded that the film represents ideological disputes between capitalism and Marxism in Cuba, as well as giving an ideal perspective on how the world should work.
\end{abstract}

Keywords: marxism, capitalism, Cuba

\begin{abstract}
ABSTRAK
Artikel menjelaskan film animasi yang dihubungkan dengan perkembangan ideology di Kuba. Penelitian ini membawa suatu pengertian ideologi dan kebijakan budaya di Kuba sebagai negara komunis. Paparan artikel dimulai dengan ringkasan cerita film, latar belakang sejarah dan penelitian, konsep ideologi, dan analisis tentang film Vampires in Havana. Penelitian menggunakan studi pustaka dan dapat disimpulkan bahwa film mampu menunjukan perbedaan ideologi antara kapitalisme dan marxisme di Kuba, juga memberikan prespektif yang ideal bagaimana dunia harus bertindak.
\end{abstract}

Kata kunci: markisme, kapitalisme, Kuba 


\section{INTRODUCTION}

\section{Summary of the Story}

Vampires in Havana (;Vampiros en La Habana!) is a Cuban animated film written by Juan Padrón. The movie was released in 1985, the film features trumpet performances by Latin jazz legend Arturo Sandoval. The movie starts with the narrator explaining that in 1870, vampires began to get organized, immigrant vampires gathered in Chicago to find a mafia-based organization, led by Johnny Terrori. In Europe, they created the Vampire Group, which resides in Dusseldorf, Germany. The Vampire Group's first elected president was the famous and legendary Count Dracula. One of Count Dracula's sons, a young scientist Werner Amadeus, worked on an anti-sun formula for vampires. After failing a couple of times with his experiments using vampire dogs, the scientist eventually succeeded, this success made his father to experiment with his formula. Surprisingly, while testing the formula at near dawn, Count Dracula was burned by the rising sunlight, and died. This made Amadeus to be jeered by other vampires, and then began living in an exile with his young nephew, Joseph Emmanuel. They moved to Cuba, there Amadeus has been using Joseph as a test subject for a formula that prevents the usually fatal effects of sunlight against vampires. Joseph Emmanuel von Dracula, known as Pepito to his friends, is unaware that he and his uncle are vampires, makes his living as a trumpet player in Havana who is also involved in an underground terrorist plots to overthrow the Cuban dictator, Gerardo Machado.

Amadeus made Pepito to drink a vitamin every month, which is actually an anti-sun formula without Pepito being aware of it. After a few years, Amadeus concluded that he was succeeded with his anti-sun formula, and then started to contact the vampire organization in Europe to let them know of his success. Amadeus wanted to give away his formula-called Vampisol-so that the other vampires can have it freely. Unfortunately, the Vampire Group disagrees with Amadeus, instead, the organization which consists of members from several countries in Europe, wanted to make a fortune from the Vampisol by selling it to other vampires around the world. Meanwhile, the Chicago group planned to sabotage the formula so that they can maintain their monopoly on indoor, artificial beach resorts for vampires. When Pepito learns of his true being, he becomes the target of a multi-pronged manhunt, making all parties involved on a wild chase through the slums of Havana.

At the film's climax, Pepito and his girlfriend was cornered by Johnny Terrori's Chicago group, tells Pepito to have some O positive blood as his last drink, the blood type which vampires consider to be the most delicious. Surpringly, Pepito spits it out in disgust, Terrori then realises that Pepito has stopped being a vampire, based on Pepito's dislike of drinking blood, his vulnerability against normal bullets - vampires can only be harmed by silver bullets - and that he is completely resistant to sunlight. Terrori loses interest in the Vampisol formula, realizing that its effect is to turn vampires into humans. However, the leader of the European Vampire Group suggests a deal with his rival from Chicago, a deal where they can encourage vampires to take small amounts of Vampisol in the summer and visit the mobsters' artificial beaches in the winter. Both groups believe that they are going to make a fortune from Vampisol, but, as a final resolution, Pepito sings instructions on how to prepare the formula over the Vampire Radio International to vampires worldwide, instructing them to use it with small amount to avoid becoming human. With this, the Vampisol formula becomes financially worthless and the two big vampire financial groups find themselves defeated. 


\section{METHODS}

The article was based on library research, through primary and secondary literature related to philosophical concepts as well history of Cuba.

\section{RESULTS AND DISCUSSIONS}

In order to analyze the film's hidden meaning and symbols, it is prudent to briefly examine the background of Cuba. Cuba's strong ideological content is reflected on their pedagogical and cultural policies that are based on Marxist ideology. If someone wants to enroll to a university, his or her options depend on how integrated that person is to Marxist ideology. Adjectives such as "Soviet", "Socialist", "People's", and "Democratic or Bolivarian" were in common use in communist states, but The Republic of Cuba is the only country in the world that has not changed names in any way following the communist revolution.

By the end of 1960, as a result of revolution, all opposition newspapers in Cuba had been closed down, and all radio and television stations were in state control.( Some homosexuals were sent to labor camps as subjects to political re-education. This doctrine even lies in the movie when two of Terrori's henchmen are trying to get a room in a love-motel in order to catch Pepito and his girlfriend Lola.

Sharpie: My friend and I need a room.

Hotel clerk: (get out) We don’t want any psychos here!

According to history, Cuba has ranked high in numbers of medical staff and has made great deal of contributions to world health since the 19th century. Today, Cuba has universal health care and plenty of medical personnel. Primary health care is available throughout the country and both infant and maternal mortality rates lower than those in developed nations. Post-Revolution Cuba experienced a hard blow in terms of disease and infant mortality rates in the 1960s when half of its 6,000 doctors/medical personnel left the country. Recovery occurred by the 1980s when the Communist government organized universal health care as a priority of state planning as well as in rural areas. This quality of public health care given to citizens is then regarded as the "greatest achievement" of Cuba's socialist system.

Another key element that lies in the movie is capitalism, which Juan Padron portrayed with the Vampire Group; a bunch of characters consist of greedy European vampires from Germany, England, Italy, and Spain. Capitalism itself is a concept related with economy where economic matters are separated from theology. Whereas economic matters were still bound to religion and churches in Middle Age era, then thinkers like Quesnay and Adam Smith suggested that economic matters were become world matters. For Quesnay and Smith, Capitalism is a concept that allows humans to be involved in free economy and be able to earn profit as much as they can without any restraint/limitation regulated by religion and even the state/government. The main principle of capitalism at that time was Laissez Faire, a concept that prohibits external authority to interfere in economic matters. Smith argued that if mankind were free to gain profit than there would be competition (as if there is an invisible hand creating order within the society without the economic practitioner's awareness). Another principle is that capitalism emphasizes production's profit to increase the capital itself (assets). With this new concept, capitalists compete with each other increase production as effective as they can, so that the capital can be accumulated and strengthening the company's finance. (Ahdian, 2006: 69). 
The Vampire Group seeks to gain a monopoly over the Vampisol product, which allows them to sell Vampisol to their fellow vampires with the highest price, making them to earn a huge fortune.

German representative: "Von Dracula wants the formula to be distributed free, free, free! Old fool! We'll hold a monopoly on the formula, Vampisun (Vampisol)! We'll be the ones to suck our colleagues dry, not that Terrori."

German representative: "Fool! Give me that paper with the formula. Free?! We'll make an empire, selling Vampisol"

In economics, a monopoly happens when an individual or a company has a significant control over a certain product or service to determine the terms on which other persons may have access to it. Monopoly is then characterized by a lack of economic competition and a lack of acceptable substitute goods.(Blinder, Baumol,\&Gale, 2001: 212). The verb "monopolize" means a process when a firm gains greater market share than what is should be under a healthy competition. The concept of monopoly has been criticized by socialist as well as Marxists, for the effect that it has in creating a huge gap between social classes:

"Ever since monopoly capital took over the world, it has kept the greater part of humanity in poverty, dividing all the profits among the group of the most powerful countries. The standard of living in those countries is based on the extreme poverty of our countries."

— Che Guevara, 1965

If the Vampire Group tries to gain a monopoly on the Vampisol, then the vampire-mafia shown on Vampires in Havana is trying to destroy it so they can make a business from developing artificial beach in Dusseldorf, Germany. The mafia—led by Johnny Terrori-plan be the boss of all vampires in the world by controlling all the beaches. The mafia that is portrayed in this movie itself means an Italian-American criminal society-organized crime-and is a branch organization of the Sicilian Mafia. The vampire-mafia in the movie seeks to control all the vampires in the world.

Mr. Goingdown: “... with our beaches, thousands of vampires in America and soon in Europe will enjoy life... that's right, the great Terrori will control all vampires of the world, sell out, or the big stake will bash you!”

Terrori is being funded by $\mathrm{Al}$ Tapone, who is a fictional character created by Paudron based on the notorious Al Capone, the leader of the Chicago mafia back in the 1930s. Al Capone's mafia is also known as The Outfit, or the Capone Gang, with its members is estimated to be between 50-200 members along with 1000 associates. Al Tapone loans his money to Terrori, with the condition that Terrori will give him back his money with $300 \%$ interest. This act is called loan sharking, an activity that is very common along Mafioso both in USA or Sicilia. In fact, according to a 2007 publication, the Italian small-business association Confesercenti reported that around 25.2\% of Sicilian businesses were indebted to loan sharks, who collected around $€ 1.4$ billion a year in payments. This number has risen especially during the late-2000s economic recession, as tighter lending by banks forces desperate businessmen to borrow from the Mafia. Below is the example of loan sharking as shown in the Vampires in Havana.

Johnny Terrori: "real sand $\mathrm{Al}$, the water's pumped from the sea with fish and everything. It'll be great Al, Duesseldorf Beach, bigger than New York Beach, San Francisco Beach, and Chicago Beach. I just need more money, Al... what do you say, Al? You can get $300 \%$ in a single year, just a few months more, Al.” 
Al Tapone: “I’ve been waiting for a long time, Johnny. I don’t see any progress with your European vampires... okay Johnny, I'll give you some more juice (money). You'll give me back 300\% two months from now, don't disappoint me Johnny. I'd be sorry if I had to put the screws on you."

If the villains are trying to enrich themselves-whether it is by getting a monopoly with the Vampisol or by controlling artificial beach resorts toward their fellow vampires-,the protagonists, Pepito and his uncle, the scientist Von Dracula aims to give away the formula to all vampires in the world, without taking advantage whatsoever. This kind of ideology resembles Cuba's ideology of Marxism/socialism that plays a vital part in removing dictatorship, prioritizing on pedagogy and public healthcare, etc. Marxism itself derives from the philosophy of Karl Marx, who was born in 1818 in Trier, Rhineland, Germany. (Woodfin \& Zarate, 2008: 6). One of his famous remark was "The history of all existing mankind and society is the history of class struggles". He thought that exploitation began when society was based on slavery-slaves were the real wealth for the dominant classes, and this system collapsed because of the contradiction within itself and then was replaced by feudalism. In the feudalism era, societies were subjected to aristocrat's-controlled land, making them unable to move freely. Feudalism was broke and then was replaced by a modern dominant production system, which is capitalism. Capitalism is a bourgeoisie revolution, which began when merchants and big cities industrialists took over the power and authority from aristocrats and forced them to comply.

Marx was influenced by David Ricardo’s (1772-1823) classic economy theory; Ricardo developed a theory about labor value. He argued that the price of a certain commodity was determined by the necessary time to develop it. Marx added that this explanation was the simplest way to understand prices for the goods sold at stores, but he saw this theory as a key fact to explain exploitation and imbalance. The essence was based on the ideas of commodity and value. In Capital, Marx defined commodities as 'materials that are able to satisfy many aspects of human's needs'. A commodity can be used by a producer or by others. But, if a commodity is used by others, then it needs to be paid, through trading or money - every commodity has an added value and trade value.

In order to become a commodity, a product needs to be given to another person who will make use of its use-value, through exchanges. In other words, a commodity is not only capable of create a use-value but also a use-value for others, or a social use-value. Unfortunately, the exchanges are never in balance, there is always financing surplus, some called it profit, but in Marxism economy, this surplus is called added value, or Capital. Capitalists are people who gain profits not from production of commodities, but from exchange value. They are bourgeoisie, middle class people who in Middle Ages era were living their life as loan sharks. In the modern era, they are factory owners and landlords that control the means of production. These middle class groups trade the means of production with the energy of labors, which produces commodities. This exchange is done in the form of salaries, because labors only have their working time to be exchanged as use-value.(Lente \& Dunleavy, 2007: 5). Added values (capital) is created by keeping the labors' salary lower than the commodities' exchange value that are produced by the labors themselves.

Another important factor is the 'means of production', such as gadgets, equipments, machineries, that are used to develop a certain commodity. These means of production evolve from time to time. New equipment allows labors to produce commodities twice as many compared with what they produced before. A trade value of a certain commodity then is reduced by half from its original price (Woodfin \& Zarate, 2008: 46). The ones that can afford to purchase new equipments are the owners of means of production, capitalists, and the bourgeoisie.

In February 1848, Karl Marx and his partner Friedrich Engels published the Communist Manifesto, which is a short book that has since been considered in history as one of the world's most 
influential political manuscripts. It describes an analytical approach to the problems of the class struggle (both historical and present) as well as the problems regarding the growth of capitalism. The book consists of 10 key important demands that were proposed by the writers themselves:

1. Abolition of property in land and application of all rents of land to public purposes.

2. A heavy progressive or graduated income tax.

3. Abolition of all rights of inheritance.

4. Confiscation of the property of all emigrants and rebels.

5. Centralisation of credit in the hands of the state, by means of a national bank with State capital and an exclusive monopoly.

6. Centralisation of the means of communication and transport in the hands of the State.

7. Extension of factories and instruments of production owned by the State; the bringing into cultivation of waste-lands, and the improvement of the soil generally in accordance with a common plan.

8. Equal liability of all to work. Establishment of industrial armies, especially for agriculture.

9. Combination of agriculture with manufacturing industries; gradual abolition of all the distinction between town and country by a more equable distribution of the populace over the country.

10. Free education for all children in public schools. Abolition of children's factory labour in its present form. Combination of education with industrial production, etc, etc.

(Source: Marx/Engels Internet Archive (marxists.org), 2000)

Marx's selflessness, anti-capitalist and socialist ideology are reflected on both Pepito and Wolfang Amadeus Von Dracula's way of thinking, especially in giving away the Vampisol formula to all vampires in the world. Even after being forced or persuaded by the capitalists and the mafia, they persevere and won't let the formula to be used as a commodity by the villains.

Wolfang Amadeus Von Dracula (the scientist): “Joseph is the living proof of the formula's effectiveness, he's tanned... Vampisol? I ilke it! I'll read the formula so everybody will have it, FREE!”

German representative:”Give it to me boy, we'll make you RICH!”

Pepe: "I'll destroy it first!"

Pepito:"Wolfang Amadeus Von Dracula discovered this formula; I'll give it to you free. The words of my song tell how to make it."

\section{CONCLUSION}

'Vampires in Havana' represents both Marxism and Cuba's cultural policy, through ideological dispute between communism and capitalism, as well as repressive doctrines on homosexuals in Havana. The movie tells that even vampires' interest are not only to frighten/terrorizing humans by feeding on their blood, but to enrich themselves and gain a fortune even by taking advantage among fellow vampires. The vampires here are shown as capitalist people that live on capitalist countries, such as Americans, Europeans, etc. But not all vampires share the same ideology; Pepito and his uncle are depicted as socialist Marxist vampires, by wanting to distribute their knowledge neither without taking advantage nor without getting a huge profit from it. The movie shows that the ideal ideology is the Marxism, just like what the Cubans do. 


\section{REFERENCES}

Ahdian, D. G. (2006).Percik Pemikiran Kontemporer. Jalasutra:Yogyakarta \& Bandung.

Blinder, A.; Baumol, W. J. and Gale, C., (2001).Microeconomics: Principles and Policy. Thomson South-Western.

Lente, F. V., \& Dunleavy, R.(2007). Filsuf Jagoan. Jakarta: KPG.

March, A., Che Guevara Studies Center \& Ocean Press (2005). Che Guevara at the Afro-Asian Conference in Algeria, Downloaded from

http://www.marxists.org/archive/guevara/1965/02/24.htm

Marx/Engels Internet Archive (marxists.org) (2000), Manifesto of the Communist Party, Downloaded from http://www.marxists.org/archive/marx/works/1848/communist-manifesto/ch02.htm

Woodfin, R. \& Zarate, O.(2008). Marxisme untuk Pemula. Yogyakarta: Resist Book. 